\title{
Peningkatan Keterampilan Menulis Puisi Siswa Kelas III SDN Bringin 1 Kecamatan Bringin Kabupaten Ngawi dengan Menggunakan Teknik Akrostik
}

\author{
Sofyan Susanto \\ PGSD STKIP Modern Ngawi
}

\begin{abstract}
Abstrak
Kompetensi dasar mata pelajaran Bahasa Indonesia merupakan kualifikasi kemampuan minimal peserta didik yang menggambarkan penguasaan pengetahuan, keterampilan berbahasa dan sikap positif terhadap bahasa dan sastra Indonesia. Standar kompetensi merupakan dasar bagi peserta didik untuk memahami dan merespon situasi lokal, regional, nasional, dan global. Dengan kompetensi tersebut diharapkan peserta didik dapat mengembangkan potensinya sesuai dengan kemampuan, kebutuhan, dan minatnya serta dapat menumbuhkan penghargaan tehadap karya sastra dan intelektual bangsa sendiri. Namun kenyataan di lapangan kompetensi yang diharapkan dari pembelajaran Bahasa Indonesia belum semuanya dapat dicapai oleh siswa. Khususnya tingkat apresiasi terhadap sastra, yang termasuk menulis puisi pada anak. Banyak anak yang kurang berminat atau kesulitan dalam menulis puisi bahkan guru banyak yang mengeluh dalam melaksanakan pembelajaran menulis puisi. Untuk menumbuhkan dan meningkatkan sikap apresiasi terhadap sastra sejak dini bagi siswa, perlu ditempuh suatu cara atau metode yang merangsang anak untuk gemar menulis puisi. Menulis puisi dengan teknik akrostik akan memberi kemudahan pada siswa dalam menulis puisi, siswa akan lebih mudah menyusun kata-kata. Penelitian ini menggunakan rancangan penelitian tindakan kelas (PTK). Berdasarkan hasil penelitian dapat disimpulkan bahwa terjadi peningkatan keterampilan siswa dalam menulis puisi dengan menggunakan teknik akrostik dan terjadi peningkatan keaktivan siswa kelas III SDN Bringin 1 Kecamatan Bringin Kabupaten Ngawi dalam pembelajaran menulis puisi dengan penerapan teknik akrostik.
\end{abstract}

Kata Kunci: menulis, puisi, teknik akrostik

\section{PENDAHULUAN}

Kompetensi dasar mata pelajaran Bahasa Indonesia merupakan kualifikasi kemampuan minimal peserta didik yang menggambarkan penguasaan pengetahuan, keterampilan berbahasa dan sikap positif terhadap bahasa dan sastra Indonesia. Standar kompetensi merupakan dasar bagi peserta didik untuk memahami dan merespon situasi lokal, regional, nasional, dan global. Dengan kompetensi tersebut diharapkan peserta didik dapat mengembangkan potensinya sesuai dengan kemampuan, kebutuhan, dan minatnya serta dapat menumbuhkan penghargaan tehadap karya sastra dan intelektual bangsa sendiri.

Namun kenyataan di lapangan kompetensi yang diharapkan dari pembelajaran Bahasa Indonesia belum semuanya dapat dicapai oleh siswa. Khususnya tingkat apresiasi terhadap sastra, yang termasuk menulis puisi pada anak. Banyak anak yang kurang berminat atau kesulitan dalam menulis puisi bahkan guru banyak yang mengeluh dalam melaksanakan pembelajaran menulis puisi. Dengan demikian perlu kiranya diupayakan untuk meningkatkan kemampuan dan minat belajar siswa dalam menulis puisi.

Untuk menumbuhkan dan meningkatkan sikap apresiasi terhadap sastra sejak dini bagi siswa, perlu ditempuh suatu cara atau metode yang merangsang anak untuk gemar menulis puisi. Dengan demikian siswa diharapkan dapat meningkatkan daya apresiasi terhadap sastra. Yaitu penghayatan terhadap nilai seni yang terkandung dalam puisi tersebut. Nilai-nilai inilah yang nantinya dapat membentuk kehalusan budi seorang siswa. 
Akhirnya anak yang belajar menulis puisi akan memiliki rasa estetika yang memadai.

Menulis puisi dengan teknik akrostik adalah bentuk penulisan puisi yang menggunakan huruf pada sebuah kata untuk memulai tiap-tiap baris dalam puisi. Semua baris dalam proses menceritakan atau mendiskripsikan topik kata penting. Menulis puisi dengan teknik akrostik akan memberi kemudahan pada siswa dalam menulis puisi, siswa akan lebih mudah menyusun kata-kata. Penelitian ini sebagai sebuah upaya peningkatan keterampilan menulis puisi melalui teknik akrostik. Penerapan teknik akrostik dalam penelitian ini memberikan rangsangan dengan menderetkan nama secara vertikal kemudian dari inisial huruf pertama tersebut, kata-kata dipilih sesuai dengan kreativitas dan imajinasi untuk mewujudkan karya puisi. Melalui metode ini keterampilan siswa dalam menulis puisi akan dianalisis secara ilmiah melalui sebuah penelitian tindakan kelas. Secara umum penelitian tindakan kelas ini bertujuan untuk mengetahui ada tidaknya peningkatkan keterampilan dalam menulis puisi pada siswa kelas III SDN Bringin 1 dengan menggunakan teknik akrostik.

Menurut Suparno dan Yunus (2007: 1.3) menulis dapat didefinisikan sebagai suatu kegiatan penyampaian pesan (komunikasi) dengan menggunakan bahasa tulis sebagai alat atau medianya. Pesan adalah isi atau muatan yang terkandung dalam suatu tulisan. Tulisan merupakan simbol atau lambang bahasa yang dapat dilihat dan disepakati pemakiannya. Dalam komunikasi bahasa tulis paling tidak terdapat unsur yang terlibat: (1) penulis sebagai penyampai pesan, (2) pesan atau isi tulisan, (3) saluran atau media berupa tulisan dan (4) pembaca sebagai penerima pesan.

Santosa dkk (2008: 6.14) menegaskan bahwa seorang penulis yang memahami dengan baik makna menulis akan betul-betul peduli terhadap kejelasan apa yang ditulis, kekuatan tulisan itu dalam mempengaruhi orang lain, keaslian pikiran yang hendak dituangkan dalam tulisan, kepiawaian penulis dalam memilih dan mengolah kata-kata.

Menurut Ghazali (2010: 335), proses menulis menghendaki pembelajar untuk menentukan bagaimana cara mereka menerapkan berbagai macam pengetahuan, seperti: kemampuankemampuan bahasa, aturan penulisan, subjek atau topik tulisan, tujuan penulisan, dan pembaca yang dituju oleh tulisan.

Puisi merupakan salah satu bentuk pengungkapan sebuah ide. Dalam sebuah puisi setiap kata adalah sesuatu yang bermakna. Kata-kata dalam puisi dapat bermakna indah, agung, ataupun angker yang bisa memancarkan sinar karismatik. Jadi tidak ada kata-kata yang mubadzir dalam sebuah karya sastra (puisi) yang diciptakan penyair. Setiap kata mengandung makna yang mampu mewakili baris-baris kalimat yang hendak ditulis oleh penyairnya.

$$
\text { Lebih lanjut Waluyo (2008: }
$$

mengemukakan bahwa puisi adalah salah satu bentuk kesusastraan yang mengungkapkan pikiran dan perasaan penyair secara imajinatif dan disusun dengan mengkonsentrasikan semua kekuatan bahasa, yakni dengan mengkonsentrasikan struktur fisik dan struktur batinnya. Pengertian senada dinyatakan Clive Sansom (dalam Waluyo, 2008: 26) puisi merupakan bentuk pengungkapan gagasan yang bersifat internasional dengan mempertimbangkan efek keindahan. Pertimbangan keindahan tersebut akan menimbulkan irama.

Teknik Akrostik merupakan salah satu jenis teknik puisi yang digunakan untuk pemula, sebagai bahan dasar untuk mulai menyukai menulis puisi. Kata akrostik berasal bahasa Prancis, Acrostiche dan bahasa Yunani, Akrostichis. Akrostik merupakan kata benda, yang artinya sebuah sajak (kata lain dari puisi, yang huruf awal baris-barisnya menyusun sebuah atau beberapa kata, apabila dibaca secara vertikal dari atas ke bawah). Pola rima dan jumlah larik dapat bervariasi, karena puisi akrostik lebih dari puisi deskripsi yang mana menjelaskan kata yang dibentuk (Aning, 2011: 2).

Dalam menulis puisi akrostik, perbendaharaan kata masing-masing berbeda. Pengalaman dalam membaca puisi sangat mempengaruhi hasil tulisan puisi. Semakin banyak dalam membaca puisi, maka semakin banyak pula kata-kata yang akan dipilihnya dan dikembangkan dalam puisinya sehingga hasil karya puisinya mempunyai nilai estetika yang semakin tinggi pula (Sudibyo, 2011: 1). 


\section{METODE}

Penelitian ini menggunakan rancangan penelitian tindakan kelas (PTK). Peneliti memilih SDN Bringin 1 sebagai tempat penelitian didasarkan beberapa pertimbangan antara lain (1) siswa kelas III SDN Bringin 1 mengalami kesulitan menulis puisi. (2) penggunaan teknik akrostik dalam menulis puisi belum pernah dilaksanakan. (3) penelitian akrostik belum pernah dilaksanakan, sehingga hasilnya diharapkan dapat memberikan manfaat untuk peningkatan pembelajaran di SDN Bringin 1.

Subjek penelitian adalah siswa kelas III SDN Bringin 1 berjumlah 32 siswa 14 perempuan 18 laki-laki. Seluruh siswa dilibatkan dalam kegiatan penelitian, karena mengikuti konteks alamiah pada proses pembelajaran yang sesungguhnya.

Penelitian ini bersifat partikular atau spesifik, penelitian ini dilakukan untuk meningkatkan ketrampilan menulis puisi siswa kelas III SDN Bringin 1. Tidak dimaksudkan untuk melakukan generalisasi dan untuk memperoleh dalil-dalil. Penelitian ini bersifat unik, penelitian tindakan kelas memandang pembelajaran dari sudut pandang orang dalam yang tidak berjarak dengan peneliti yakni penelitian dilaksanakan oleh peneliti sekaligus sebagai pelaku pengajar Bahasa Indonesia di kelas III SDN Bringin 1 dengan pelaksanaan bersama dengan kegiatan pembelajaran yang berlangsung seperti biasa tanpa mengubah jadwal.

Penelitian ini bersifat kolaboratif, penelitian ini dilaksanakan bekerja sama dengan guru teman sejawat dengan melaksanakan diskusi, observasi dari kondisi awal, menyusun perencanaan masuk bersama dalam kelas, memberi masukan pelaksanaan, mengamati pelaksanaan, membuat observasi, dan menilai jalannya kegiatan pembelajaran, melaksanakan refleksi menyampaikan kelebihan dan kekurangan selama kegiatan sehingga mampu mencapai tujuan penelitian.

Sesuai dengan jenis penelitian yang dipilih, yaitu penelitian tindakan, maka penelitian ini menggunakan model penelitian tindakan dari Kemmis dan Taggart (dalam Wiriaatmadja, 2005: 65), yaitu berbentuk spiral dari siklus yang satu ke siklus yang berikutnya. Setiap siklus meliputi planning (rencana), action (tindakan), observation (pengamatan), dan reflection (refleksi). Langkah pada siklus berikutnya adalah perncanaan yang sudah direvisi, tindakan, pengamatan, dan refleksi. Sebelum masuk pada siklus 1 dilakukan tindakan pendahuluan yang berupa identifikasi permasalahan.

\section{HASIL DAN PEMBAHASAN}

\section{A. Hasil}

\section{Deskripsi Sebelum Tindakan}

Sebelum tindakan dalam penelitian ini, peneliti melakukan uji awal kepada siswa dengan cara memberi tugas rumah untuk membuat puisi bebas. Pada saat pembahasan tugas rumah tersebut, peneliti melakukan wawancara yang dilakukan secara lisan dan klasikal. Peneliti mengajukan beberapa pertanyaan dengan jawaban ya/tidak dan siswa menjawabnya dengan angkat tangan. Peneliti menghitung dan mencatat hasil jawabannya. Dari hasil wawancara diperoleh data bahwa prosentase siswa yang membuat puisi sendiri hanya $21,9 \%$, yang meniru $25 \%$ dan yang belum bisa membuat puisi $53,1 \%$. Sedangkan prosentase yang menyukai menulis puisi hanya $37,5 \%$ dan yang tidak suka menulis puisi $62,5 \%$.

Pada saat pembelajaran dengan teknik akrostik dengan menugaskan siswa untuk membuat sebuah puisi bebas, terlihat siswa sangat kebingungan, tidak semangat, dan lama tidak segera memulai. Hal ini menunjukkan rendahnya keaktivan siswa dalam membuat puisi, dan sampai akhir batas yang ditentukan sebagian besar siswa tidak bisa menyelesaikan tugasnya.

Dari data tersebut dapat disimpulkan bahwa kemampuan awal menulis puisi siswa masih rendah dan diperlukan upaya-upaya untuk meningkatkan kemampuan siswa serta perlunya motivasi dari guru dalam pembelajaran menulis puisi.

\section{Deskripsi Siklus I}

\section{a. Perencanaan}

Perencanaan tindakan yang disusun meliputi: (1) pembuatan Rencana 
Pelaksanaan Pembelajaran (RPP); penyiapan Instrumen Penelitian; (3) Contoh puisi Akrostik; serta (4) penyiapan Lembar Kegiatan Siswa (LKS). Rencana pelaksanaan pembelajaran menulis puisi dirancang menggunakan teknik akrostik yang mengacu pada Kurikulum Tingkat Satuan Pendidikan.

Pada tahap perencanaan siklus I meliputi kegiatan sebagai berikut. Materi pembelajaran yang disiapkan adalah materi menulis puisi yang mengacu pada standar kompetensi: mengungkapkan pikiran, perasaan, dan informasi dalam karangan sederhana dan puisi. Kompetensi dasar: menulis puisi berdasarkan gambar dengan pilihan kata yang menarik. Dari hasil diskusi dengan teman sejawat dalam kolaborasi disepakati bahwa karena keterampilan dasar menulis puisi bagi kelas III SD masih perlu adanya pembinaan, maka menulis puisi tidak berdasarkan gambar tetapi dengan teknik akrostik.

Peneliti menyusun perangkat pembelajaran, berupa pengembangan kompetensi dasar ke dalam perangkat pembelajaran, Lembar Kerja Siswa, dan menyiapkan format penilaian. Peneliti menyusun pedoman observasi untuk mengamati aktivitas siswa selama kegiatan pembelajaran berlangsung. Peneliti menyusun pedoman observasi untuk mengamati aktivitas guru selama kegiatan pembelajaran berlangsung.

Peneliti merencanakan skenario pembelajaran dengan teknik Akrostik sebagai berikut: Pendahuluan: (Salam Pembuka, Guru mengkondisikan situasi kelas, Guru menjelaskan tujuan pembelajaran, Guru menjelaskan langkah-langkah pembelajaran, Pembentukan kelompok), (2) Kegiatan Inti: (1) tahap pramenulis (Guru menjelaskan cara membuat puisi dengan teknik akrostik, Menguraikan unsur- unsur puisi, (2) tahap menulis puisi (Siswa berdiskusi untuk membangkitkan inspirasi dari puisi yang dipilih, Siswa mencari pilihan kata/diksi yang sesuai, Siswa menyusun diksi menjadi puisi yang menarik dengan membuat puisi akrostik berdasarkan nama anggota kelompok yang paling panjang huruf/katanya. (3) tahap pasca menulis: (Membacakan puisi hasil karyanya di depan kelas, Menanggapi hasil karya kelompok yang tampil, Melakukan revisi atau editing, Guru dan siswa menyimpulkan tentang menulis). Penutup: (Pemberian refleksi setelah pembelajaran, Pemberian penguatan dan tindak lanjut, Salam penutup.)

\section{b. Pelaksanaan Tindakan}

Pada pelaksanaan tindakan siklus I, kelas dalam keadaan siap untuk dilaksanakan penelitian. Seluruh siswa hadir, dan ada kesediaan untuk mengikuti pembelajaran. Teman sejawat sebagai tim kolaborasi juga siap untuk memberikan pengamatan terhadap aktivitas siswa maupun aktivitas guru selama pembelajaran berlangsung. Pada tahap pelaksanaan ini guru menyajikan langkah-langkah pembelajaran sesuai skenario pembelajaran dengan urutan tindakan akan diuraikan sesuai dengan tahap menulis puisi.

\section{1) Tahap Pramenulis}

Kegiatan pembelajaran menulis puisi dengan teknik akrostik yang dilaksanakan guru pada tahap pramenulis dengan diawali dengan salam dan doa. Guru berusaha mengkondisikan situasi kelas dan siswa terlihat langsung menyesuaikan diri dalam situasi belajar di kelas. Kemudian guru menyampaikan tujuan pembelajaran. Guru juga memberikan motivasi kepada 
siswa agar mengikuti pelajaran terutama tentang kemampuan menulis puisi. Siswa terlihat antusias untuk mengikuti pelajaran. Selanjutnya guru menjelaskan langkah-langkah pembelajaran yang akan dilaksanakan. Kemudian siswa dibentuk kelompok dengan anggota masing-masing beranggotakan 4 orang siswa. Setelah terbentuk kelompok siswa duduk bersama dengan kelompoknya. Kemudian guru menjelaskan cara menulis puisi dengan teknik akrostik. Untuk memperjelas pengertian akrostik, guru melakukan tanya jawab untuk memancing kemampuan siswa mengeluarkan perbendaharaan kata dengan pertanyaanpertanyaan: "Anak coba cari kata-kata yang diawali dengan huruf S?", dengan pertanyaan tersebut siswa bersaut-sautan menjawab. Kemudian guru melanjutkan pertanyaan dengan huruf yang lain.

\section{2) Tahap Menulis}

Kegiatan pembelajaran yang dilaksanakan dalam tahap menulis didahului dengan menjelaskan unsur-unsur pembentuk puisi. Selanjutnya guru membagikan LKS. Tugas utama dalam LKS adalah membuat puisi secara berkelompok dengan teknik akrostik. Yang digunakan sebagai dasar akrostik adalah nama lengkap siswa yang paling panjang. Siswa terlihat bersemangat memilih kata-kata yang sesuai untuk puisi yang dibuat. Guru terlihat aktif membimbing dalam penyempurnaan unsur puisi.

\section{c. Observasi}

1) Observasi Aktivitas Guru

Rumusan masalah dan kesesuaian teknik dengan tujuan yang dibuat guru sudah baik dan sesuai dengan tema, Pemilihan bahan ajar berupa photo copy contoh-contoh puisi dengan teknik akrostik sebaiknya lebih banyak. Pengorganisasian materi ajar perlu penjelasan rinci di perencanaan untuk masing-masing tahap menulis. Sumber/media pembelajaran hanya satu jenis saja. Skenario pembelajaran yang dirancang sudah baik tetapi kurang sistematis. Kelengkapan instrumen yang disusun guru perlu dilengkapi dengan pedoman yang lebih jelas. Secara umum perencanaan yang dibuat guru dalam pelaksanaan penelitian ini sudah baik dan layak, namun perlu perbaikan agar lebih sempurna. Secara umum perencanaan pembelajaran yang dibuat oleh guru sudah baik dengan skor 3,3. Tetapi masih perlu untuk disempurnakan lagi.

Pengelolaan kelas dilakukan dengan cara membentuk kelas menjadi 8 kelompok dengan masing-masing kelompok beranggotakan 4 siswa cukup sesuai, tapi waktu pengaturan kurang efektif. Kegiatan appersepsi yang dilakukan guru kurang tegas. Penguasaan materi sudah baik, tapi penyampaian ke siswa masih perlu disertai contoh yang sesuai dengan karakteristik siswa. Kegiatan yang dilakukan dengan rencana sudah sesuai dan dilakukan dengan baik. Penguasaan kelas yang dilakukan guru perlu dilakukan secara menyeluruh terhadap semua siswa dan perlu berkeliling untuk 
membimbing perkelompok. Penggunaan bahasa sudah cukup tetapi masih banyak yang diulangulang. Kemampuan mengaktifkan siswa masih perlu ditingkatkan. Kemampuan menggunakan teknik akrostik sudah baik tapi belum efektif. Kemampuan membimbing dan memotivasi siswa sudah baik tapi kurang menyeluruh. Pengelolaan waktu sudah baik. Penilaian proses masih belum nampak, tapi secara tertulis sudah dilakukan. Menutup pelajaran dengan salam, namun kurang diberikan penguatan. Secara umum pelaksanaan pembelajaran yang dilakukan guru sudah baik, tapi perlu disempurnakan.

\section{2) Observasi Aktivitas Siswa}

Antusias siswa dapat dilihat dari kemauan siswa mengerjakna tugas sesuai dengan petunjuk guru. Kemauan siswa sudah cukup, tapi masih perlu motivasi dari guru. Kemauan siswa mengajukan pertanyaan kepada guru apabila ada petunjuk yang kurang dimengerti kurang tampak dalam pelaksaan pembelajaran. Kemauan siswa mempresentasikan hasil kerja masih banyak yang malu dan perlu berkali-kali menyuruh. Kemauan siswa memberikan tanggapan dan saran terhadap hasil pekerjaan temannya hanya sebagian siswa saja. Kemauan siswa mengerjakan tugas dari guru sudah baik, tapi belum nampak semangat yang kuat dari siswa. Secara umum antusias belajar menulis puisi dengan teknik akrostik sudah baik dan perlu ditingkatkan motivasinya.

Rasa ingin tahu cara membuat puisi dengan teknik akrostik disambut siswa dengan baik dengan banyak bertanya dengan guru maupun sesama temannya. Kemauan mengemukaan ide dalam penemuan diksi masih didominasi anggota kelompok yang pandai. Kemauan berpikir dan tidak putus asa mencari jawaban belum menunjukkan sikap yang memuaskan. Hasil karya yang dihasilkan belum berani dipamerkan atau masih disembunyikan karena ada rasa takut tidak menarik. Kreativitas sudah cukup tapi belum maksimal.

Pada saat membuat tugas menulis puisi dengan akrostik tampak keceriaan dan kerianggembiraan dalam belajar. Tidak terlihat siswa yang mengantuk/malas selama kegiatan belajar. Pada saat presentasi hasil kerja, sebagian kecil yang bertepuk tangan. Pada saat pembelajaran hanya sebagian saja yang menunjukkan keceriaan dengan tertawa. Rasa senang sudah tampak dalam pembelajaran menulis puisi, tapi belum tercermin saat mengerjakan tugas.

Kemauan siswa melakukan tanya jawab dengan guru sudah baik. Kemauan siswa melakukan tanya jawab dan berdiskusi dengan temannya sudah tampak, namun belum mampu menjadi sebuah dialog. Kemauan siswa bekerjasama dengan temannya sudah baik dan terkoordinasi dengan baik. Interaksi siswa sudah terlihat baik antara siswa dengan guru maupun antar siswa.

\section{d. Refleksi}

Pelaksanaan pembelajaran dapat berjalan seperti skenario yang telah dibuat. Namun sebelum pelaksanaan tahap inti pembelajaran siswa banyak yang bertanya tentang penjelasan langkah-langkah pembelajaran, dan guru dapat menyikapi dengan 
mengulang penjelasan langkah-langkah pembelajaran kepada siswa.

\section{B. Pembahasan}

\section{Pembahasan Hasil Tes}

Indikator keberhasilan pada pelaksanaan penelitian tindakan ini adalah dengan adanya peningkatan hasil tes dan dikatakan telah berhasil apabila prosentase ketuntasan telah mencapai diatas $70 \%$. Hasil tes pada penelitian tindakan tentang peningkatan keterampilan menulis puisi siswa kelas III SDN Bringin 1 dengan menggunakan teknik akrostik telah dilaksanakan selama 3 siklus. Tes yang dilakukan adalah pemberian tugas membuat puisi dan aspek yang dinilai meliputi isi, diksi, rima, dan struktur. Dari tes pada ketiga siklus tersebut diperoleh data sebagaimana tabel berikut ini.

Tabel 1. Data Hasil Tes dan Prosentase Ketuntasan

\begin{tabular}{|c|c|c|c|c|}
\hline No & Penilaian & $\begin{array}{c}\text { Rata- } \\
\text { rata }\end{array}$ & $\begin{array}{c}\text { Prosentase } \\
\text { Ketuntasan }\end{array}$ & Ket \\
\hline 1. & $\begin{array}{c}\text { Tes Akhir } \\
\text { Siklus I }\end{array}$ & 65,31 & $56,25 \%$ & \\
\hline 2. & $\begin{array}{c}\text { Tes Akhir } \\
\text { Siklus II }\end{array}$ & 67,66 & $68,75 \%$ & $\begin{array}{c}\text { Mening } \\
\text { kat }\end{array}$ \\
\hline 3. & $\begin{array}{c}\text { Tes Akhir } \\
\text { Siklus III }\end{array}$ & 71,41 & $75 \%$ & Berhasil \\
\hline
\end{tabular}

Berdasarkan tabel hasil tes diatas, dapat dikatakan bahwa rata-rata hasil tes dan prosentase ketuntasan belajar pada masingmasing siklus terdapat peningkatan dan diakhir siklus III hasil tes menunjukkan rata-rata telah mencapai 71,41 dan prosentase ketuntasan telah mencapai $75 \%$. Hal ini membuktikan bahwa pembelajaran penggunaan teknik membaca akrostik dapat meningkatkan keterampilan menulis puisi siswa kelas III SDN Bringin 1.

\section{Pembahasan Hasil Pengamatan Aktivitas Guru}

Indikator keberhasilan pada pelaksanaan penelitian tindakan ini juga didasarkan pada hasil pengamatan terhadap aktivitas guru. Aktivitas guru dapat dikatakan telah layak apabila hasil pengamatan yang dilakukan oleh pengamat dengan klasifikasi skor baik, yakni dengan rata-rata telah mencapai skor 4. Hasil pengamatan pada penelitian tindakan tentang kemampuan guru dalam merencanakan dan melaksakan pembelajaran membaca cepat siswa kelas III SDN Bringin 1 dengan menggunakan teknik akrostik telah dilaksanakan selama 3 siklus dan diperoleh data skor pengamatan sebagaimana tabel berikut ini.

Tabel 2. Data Hasil Pengamatan Aktivitas Guru

\begin{tabular}{|c|c|c|c|c|}
\hline \multirow[b]{2}{*}{ No } & \multirow{2}{*}{$\begin{array}{c}\text { Pengam } \\
\text { atan } \\
\text { Guru }\end{array}$} & & & \multirow[b]{2}{*}{ Ket } \\
\hline & & $\begin{array}{c}\text { Perencanaan } \\
\text { (RPP) }\end{array}$ & $\begin{array}{c}\text { Kegiatan } \\
\text { Pembelajaran }\end{array}$ & \\
\hline 1. & Siklus I & 3,3 & 3,1 & \\
\hline 2. & Siklus II & 3,6 & 3,5 & $\begin{array}{c}\text { Mening } \\
\text { kat }\end{array}$ \\
\hline 3. & $\begin{array}{c}\text { Siklus } \\
\text { III }\end{array}$ & 4,0 & 4,1 & $\begin{array}{c}\text { Mening } \\
\text { kat }\end{array}$ \\
\hline
\end{tabular}

Berdasarkan tabel di atas, data menunjukkan bahwa hasil pengamatan terhadap aktivitas pembelajaran yang dilakukan oleh guru ada peningkatan. Pada siklus III skor perencanaan telah menunjukkan skor 4 dan skor kegiatan pembelajaran menunjukkan skor 4,1 yang berarti telah mendapat skor dengan kualifikasi baik.

Hal ini membuktikan bahwa pembelajaran menulis puisi dengan teknik akrostik pada siswa kelas III SDN Bringin 1 dapat dilaksanakan oleh guru dan memungkinkan untuk dikembangkan dalam pembelajaran menulis puisi pada tingkat pemula. Dengan demikian aktivitas guru dalam melaksanakan pembelajaran sudah layak untuk mendukung keabsahan pelaksanaan penelitian. 


\section{Pembahasan Hasil Pengamatan Aktivitas Siswa}

Hasil pengamatan dari penelitian ini juga menjadi indikator keberhasilan pada pelaksanaan penelitian tindakan ini. Aktivitas siswa dapat dikatakan telah meningkat daya kreativitasnya apabila hasil pengamatan yang dilakukan oleh pengamat terhadap aktivitas siswa dengan klasifikasi skor baik, yakni dengan rata-rata nilai diatas skor 4.

Hasil pengamatan pada penelitian tindakan tentang aktifitas siswa selama berlangsungnya pembelajaran membaca cepat siswa kelas III SDN Bringin 1 yang telah dilaksanakan selama 3 siklus diperoleh data skor pengamatan seperti tabel berikut ini.

Tabel 3. Data Hasil Pengamatan Aktivitas Siswa

\begin{tabular}{|c|c|c|c|c|c|c|}
\hline \multirow{2}{*}{ No } & \multirow{2}{*}{$\begin{array}{c}\text { Pengamatan } \\
\text { Siswa }\end{array}$} & $\begin{array}{c}\text { Antu } \\
\text { sias }\end{array}$ & $\begin{array}{c}\text { Kreativ } \\
\text { itas }\end{array}$ & $\begin{array}{c}\text { Rasa } \\
\text { Senang }\end{array}$ & $\begin{array}{c}\text { Inter } \\
\text { aksi }\end{array}$ & \multirow{2}{*}{ Ket. } \\
\hline & Siklus I & 3,3 & 3,0 & 4,25 & 4,0 & \\
\hline \multirow{2}{*}{} & Siklus II & 3,7 & 3,75 & 4,5 & 4,3 & Meningkat \\
\hline & Siklus III & 4,3 & 4,25 & 4,75 & 4,7 & Meningkat \\
\hline
\end{tabular}

Berdasarkan tabel 5.3 hasil pengamatan aktivitas siswa diatas, rata-rata skor telah mencapai diatas 4,0 sehingga dapat dikatakan bahwa pembelajaran menulis puisi siswa kelas III SDN Bringin 1 dengan menggunakan teknik membuktikan bahwa ada peningkatan keaktivan, kreativitas, rasa senang, dan interaksi pada diri siswa dalam pembelajaran.

Shahnon (dalam Waluyo, 2008:7) menyimpulkan bahwa pengertian puisi di atas terdapat garis-garis besar tentang puisi itu sebenarnya. Unsur-unsur itu berupa emosi, imajinas, pemikiran, ide, nada, irama, kesan pancaindera, susunan kata, kata kiasan, kepadatan, dan perasaan yang bercampur-baur.

Dari definisi tersebut dapat disimpulkan bahwa puisi adalah ungkapan perasaan, emosi, ide yang disampaikan dalam bahasa yang indah susunannya dan mempunyai makna yang luas. Puisi merupakan wujud dari pengalaman penulisnya dalam bentuk bahasa yang memiliki makna yang dalam.

Puisi Akrostik merupakan salah satu jenis puisi yang digunakan untuk pemula, sebagai bahan dasar untuk mulai menyukai menulis puisi. Kata akrostik berasal bahasa Prancis, Acrostiche dan bahasa Yunani Akrostichis. Akrostik: kata benda, yang artinya sebuah sajak (kata lain dari puisi, yang huruf awal baris-barisnya menyusun sebuah atau beberapa kata, apabila dibaca secara vertical dari atas ke bawah). Pola rima dan jumlah larik dapat bervariasi, karena puisi akrostik lebih dari puisi deskripsi yang mana menjelaskan kata yang dibentuk (Aning, 2011: 2).

Hasil penelitian yang diperoleh memberikan gambaran dan bukti bahwa siswa kelas III SDN Bringin 1 kabupaten Ngawi dapat melaksanakan pembelajaran untuk membuat puisi dengan teknik akrostik dengan baik dan dapat menumbuhkan keaktifan belajar terutama dalam menulis puisi.

\section{PENUTUP}

\section{A. Simpulan}

Teknik akrostik merupakan metode dengan cara memberikan rangsangan dengan menderetkan nama secara vertikal kemudian dari inisial huruf pertama tersebut, kata-kata dipilih sesuai dengan kreativitas dan imajinasi untuk mewujudkan karya puisi.

Berdasarkan hasil penelitian dapat disimpulkan bahwa terjadi peningkatan keterampilan siswa dalam menulis puisi dengan menggunakan teknik akrostik dan terjadi peningkatan keaktifan siswa kelas III SDN Bringin 1 dalam pembelajaran menulis puisi dengan penerapan teknik akrostik.

Hasil tes dan prosentase ketuntasan belajar pada masing-masing siklus terdapat peningkatan dan di akhir siklus III hasil tes 
menunjukkan rata-rata telah mencapai 71,41 dan prosentase ketuntasan telah mencapai $75 \%$. Hal ini membuktikan bahwa pembelajaran penggunaan teknik membaca akrostik dapat meningkatkan keterampilan menulis puisi siswa kelas III SDN Bringin 1.

Sementara itu hasil pengamatan terhadap aktivitas pembelajaran yang dilakukan oleh guru ada peningkatan. Pada siklus III skor perencanaan telah menunjukkan skor 4 dan skor kegiatan pembelajaran menunjukkan skor 4,1 yang berarti telah mendapat skor dengan kualifikasi baik.

Berdasarkan hasil observasi keaktivan belajar siswa, antusias siswa menunjukkan skor 4,0 (baik), kreativitas siswa menunjukkan skor 4,3 (baik), Rasa senang siswa terhadap menulis puisi menunnjukkan skor 4,3 (baik), dan interaksi siswa menunjukkan skor 4,3 (baik). Dari data tersebut menunjukkan bahwa keaktivan siswa dalam belajar pada siklus III sudah dapat diklasifikasikan baik, Hal ini membuktikan bahwa pembelajaran menulis puisi dengan teknik akrostik pada siswa kelas III SDN Bringin 1 dapat dilaksanakan oleh guru dan memungkinkan untuk dikembangkan dalam pembelajaran menulis puisi pada tingkat pemula.

Peningkatan kemampuan menulis puisi dengan teknik ini mampu memotivasi siswa bahwa menulis puisi itu mudah dan dapat dilakukan sejak masih kelas rendah dan dapat merangsang untuk memunculkan inspirasi-inspirasi untuk menyusun kalimat yang mengandung unsur puisi.

\section{B. Saran}

Pembelajaran akan lebih menarik jika guru lebih memperhatikan minat siswa. Variasi dalam menyampaikan materi akan menentukan bagaimana respon siswa dalam proses pembelajaran. Dalam proses menyampaikan materi guru harus lebih jelas, agar waktu pembelajaran lebih efisien dan waktu siswapun tidak terbuang sia-sia.

\section{DAFTAR PUSTAKA}

Aning. 2011. Puisi Akrostik. http://aningpuisi.blogspot.com (Di unduh 12 Juli 2017)

Ghazali, S. 2010. Pembelajaran Keterampilan Berbahasa dengan Pendekatan KomunikatifInteraktif. Bandung: Refika Aditama.

Santoso, dkk. 2008. Materi dan Pembelajran Bahasa Indonesia SD. Jakarta: Universitas Terbuka.

Sudibyo, A. 2011. Teknik Menulis Puisi Akrostik. http://republikpuisi-reeve.blogspot.com. (Di unduh 12 Juli 2017)

Suparno \& Yunus, M. 2007. Ketrampilan Dasar Menulis. Jakarta: Universitas Terbuka.

Waluyo, H. J. 2008. Pengkajian dan Apresiasi Puisi. Salatiga: Widya Sari Press.

Wiriaatmadja.S. 2006. Metode Penelitian Tindakan Kelas. Bandung: Remaja Rosdakarya. 